\title{
Comparative Study between Transoral Laser Microsurgery and Transoral Videolaryngoscopic Surgery in Benign Laryngeal Tumors
}

\author{
Ji Ah Song, Chang Hoi Kim, Jun Sang Cha, Sung Won Kim, \\ Kang Dae Lee, and Hyoung Shin Lee \\ Department of Otolaryngology-Head and Neck Surgery, Kosin University College of Medicine, Busan, Korea
}

\author{
양성 후두 종양에서 경구강 레이저 수술과 경구강 비디오 수술의 비교 연구 \\ 송지아 · 김창회 · 차준상 · 김성원 · 이강대 · 이형신 \\ 고신대학교 의과대학 이비인후과학교실
}

Received April 3, 2019

Revised June 5, 2019

Accepted June 10, 2019

Address for correspondence

Hyoung Shin Lee, MD, PhD

Department of Otolaryngology-

Head and Neck Surgery,

Kosin University

College of Medicine,

262 Gamcheon-ro, Seo-gu,

Busan 49267, Korea

Tel $+82-51-990-6470$

Fax $+82-51-990-3257$

E-mailssego78@daum.net
Background and Objectives Surgical resection is the basic treatment for benign laryngeal tumors and transoral laser microsurgery (TLM) has been used effectively. Transoral videolaryngoscopic surgery (TOVS) is another method of surgical resection that has been introduced. However, there have not been any studies related to the usefulness of TOVS in benign laryngeal tumors. The purpose of this study was to compare the efficacy and surgical outcomes of TLM and TOVS.

Subjects and Method A retrospective chart review of 85 patients were conducted. This review included two groups (TLM group, $n=44$ versus TOVS group, $n=41$ ) of patients who underwent transoral surgery for benign laryngeal tumors. Clinicopathologic factors of the patients and surgical outcomes such as the operation time, amount of intraoperative bleeding, hospital stay, and complications were compared between two groups.

Results There were no significant differences between two groups regarding the clinicopathologic factors and surgical outcomes. The TOVS group presented relatively larger tumor size ( $p=0.067)$ and showed a tendency of shorter operation time $(36.8 \pm 34.5 \mathrm{~min})$ compared to that of TLM (45.6 $\pm 27.9 \mathrm{~min})$, but with no statistical significance $(p=0.199)$.

Conclusion TOVS may be considered as an alternative surgical method for benign laryngeal tumors.

Korean J Otorhinolaryngol-Head Neck Surg 2020;63(2):71-5

Key Words Laryngeal neoplasm · Laser · Microsurgery · Video-assisted surgery.

\section{서 론}

양성 후두 종양은 두경부 영역에서 비교적 흔한 질환으로 주증상은 음성변화와 천명이며 종양의 크기와 위치에 따라서 목의 이물감이나 경부 종물을 보일 수 있고 대부분의 경우 후두내시경검사를 시행하여 병변을 확인할 수 있다. ${ }^{1)}$ 양성

This is an Open Access article distributed under the terms of the Creative Commons Attribution Non-Commercial License (https://creativecommons.org/licenses/by-nc/4.0) which permits unrestricted non-commercial use, distribution, and reproduction in any medium, provided the original work is properly cited.
후두 종양에 대한 치료로는 외과적 절제가 기본이 되며, 주 로 경구강 레이저 수술(transoral laser microsurgery, TLM) 이 효과적으로 사용되고 있다. TLM은 개방 수술과 비교했을 때 최소 침습적 접근이 가능하고 합병증의 비율이 낮으며 수 술 이후 회복 기간 또한 빠르다는 장점이 있어 ${ }^{2)} 1972$ 년 Strong과 Jako ${ }^{3}$ 에 의해 소개된 이후 널리 시행되었다. 또한 확 대된 영상으로 세밀한 조작이 가능할 뿐만 아니라 레이저의 지혈 효과를 이용하여 후두 병변을 제거하는 데 적절하다.4-8)

2010년 Shiotani 등)에 의해 두경부 종양의 외과적 절제의 
또 다른 방법으로 경구강 비디오 수술(transoral videolaryngoscopic surgery, TOVS)이 소개되었고 후두, 하인두, 구인두 ${ }^{10)}$ 의 악성 종양에 적용 가능하였다는 보고가 있었다. 이 수술 방 법에서는 보조의가 적절한 수술 시야를 얻기 위해 경성 후두 경(rigid laryngoscope)을 조작하면 집도의가 모니터에서 내시 경 시야를 보며 양손으로 내시경용 수술 도구를 조작한다. ${ }^{9-12)}$

TLM에 의한 양성 후두 종양 수술 관련 연구들은 이미 상 당수 보고된 바 있으나, ${ }^{13)} \mathrm{TOVS}$ 의 경우 악성 종양에서의 결 과만 보고되어 있다. 이에 본 연구에서는 수술이 필요한 양 성 후두 종양 환자들을 TLM 환자군과 TOVS 환자군으로 나누어 임상양상 및 수술 결과를 비교 분석하고자 하였다.

\section{대상 및 방법}

\section{연구 대상}

2009년 1월에서 2018년 1월까지 고신대학교 복음병원 이 비인후과에서 양성 후두 종양에 대해 TLM 또는 TOVS를 시행 받은 환자들을 대상으로 후향적인 차트 분석을 하였다. 수술 전에 경부 수술 또는 방사선 치료를 받은 경우, 다발성 병변인 경우, 성대 병변인 경우, 수술 전후 조직검사 결과에 서 악성으로 의심되거나 확인된 환자는 본 연구 대상에서 제 외하였다. TLM군 44명, TOVS군 41명으로 총 85명의 환자가 연구에 포함되었다. 본 연구는 고신대학교 복음병원 기관생 명윤리위원회의 승인을 받았다(IRB No. 2019-10-005).

\section{연구 방법}

\section{수술 방법}

환자 모두에게 전신마취를 하였으며, 병변을 노출시키기 위 해 경성 후두경(Weerda distending laryngoscope, 8858 BV,
Karl Storz, Tuttlingen, Germany)을 구강으로 삽입하였다. 4 $\mathrm{mm}$ 직경의 내시경(8575 AV, 15 degree; Karl Storz)을 카메라 (22220150 Image 1 HD H3 3-chip, Karl Storz)와 연결해 후두 경에 삽입하여 적절한 수술 시야가 모니터에 나타날 수 있도록 하였다(Figs. 1 and 2). 병변의 절제 부위를 결정한 후에 내시경 용 전기 소작 기구[hook-type(26870UF, Karl Storz), needletype(26167NX, Karl Storz)]와 seperating forceps(30721MD, Karl Storz)을 사용하여 병변을 절제하였고 출혈 부위나 노출 된 혈관이 있는 부위에는 전기 소작기의 지혈 모드 또는 흡입 형 보비(suction bovie)를 사용하였다. 집도의는 양손으로 기구 를 사용하여 한손으로는 병변을 견인하고 다른 손으로는 전기 소작기를 조작하여 병변의 범위를 파악하면서 수술을 진행하 였다. 내시경은 경성 후두경의 내시경 삽입관에 고정해서 사용 하거나 수술 시야가 불충분한 경우 보조의가 경성 후두경 내 로 직접 삽입하여 집도의의 요청에 따라 병변과 절제 부위를 관찰할 수 있도록 하였다.

\section{임상병리학적 요인 및 수술 중 수술 후 소견}

임상병리학적 요인 및 수술 중 수술 후 소견을 평가하기 위 해 환자의 연령, 성별, 체질량 지수, 종양의 종류 및 크기, 수술 시간, 수술 중 출혈량, 수술 후 합병증, 평균재원기간 등을 분 석하였다. 수술 시간과 수술 중 출혈량은 마취기록지를 바탕 으로 분석하였고 종양의 종류 및 크기는 수술 후 조직병리 검 사 결과를 기준으로 하였다. 또한 수술 중 및 수술 후 발생할 수 있는 합병증 여부를 평가하여 두 군 간에 비교 분석하였다.

\section{통계 분석}

통계적 분석은 SPSS 24.0(IBM Corp., Armonk, NY, USA) 을 이용하였고 두 군과 연관된 명목변수들은 chi-square test 또는 Fisher's Exact test로 분석하였다. 연속변수에 대한 평균
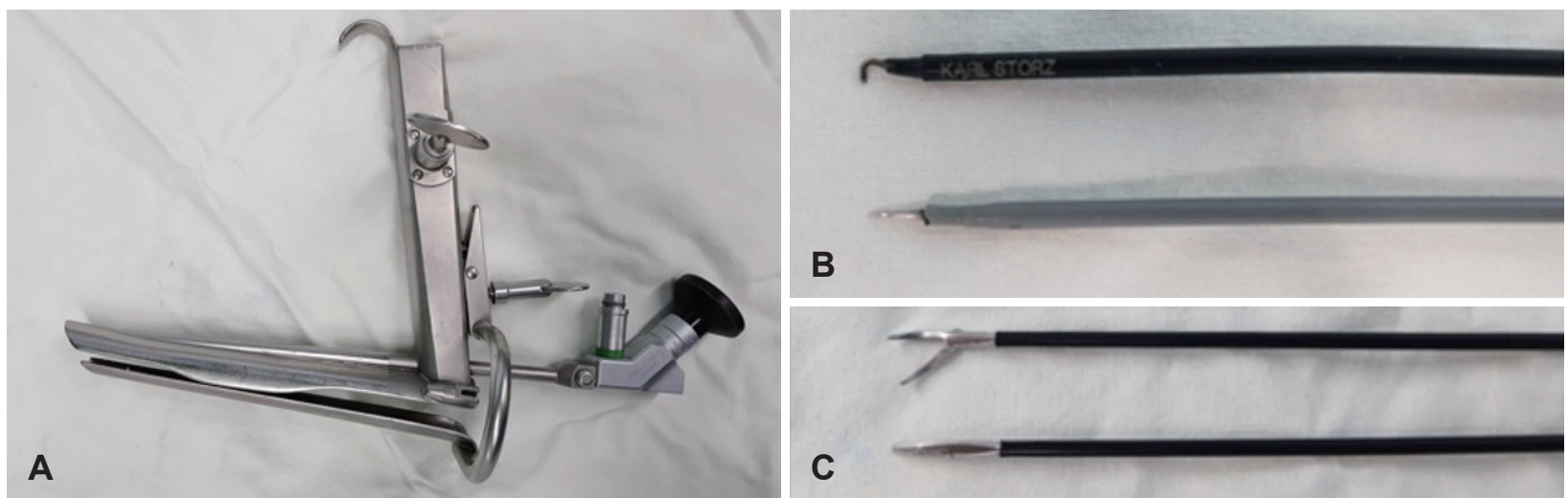

Fig. 1. Instruments of transoral videolaryngoscopic surgery. Distending laryngoscope combined with a rigid endoscope (A). Laparoscopic hook-type, needle-type scalpel (B). Laparoscopic seperating forceps (C). 

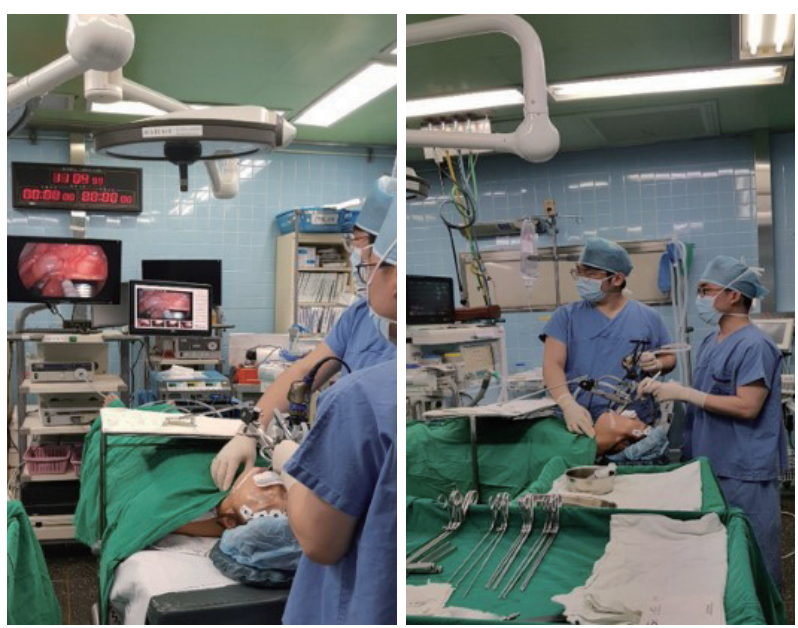

Fig. 2. Transoral videolaryngoscopic surgery setting in operation room. Surgeon performs surgery by bimanual handling of the surgical instruments while viewing the monitor.

비교는 Student t-test를 이용하여 분석하였다. 모든 항목에서 $p$ value 0.05 미만을 통계적으로 유의한 것으로 평가하였다.

\section{결 과}

\section{임상병리학적 요인}

$\mathrm{TLM}$ 군은 총 44명으로 평균 나이 $48.5 \pm 13.7$ 세, 남녀비가 26 대 18 이었고 TOVS군은 총 41명으로 평균 나이 $52.5 \pm$ 12.7세, 남녀비는 27 대 14이었다. 체질량 지수, 치아의 유무, 항응고와 연관된 약물 투약 여부, 혈관 관련성 만성 질환의 유무, 병리학적 진단명, 종양의 크기는 표에 기술하였으며 상 기 요인들에 통계학적으로 유의한 차이는 없었다(Table 1).

\section{수술 결과}

수술 소요 시간은 TLM군이 45.6 \pm 27.9 분, TOVS군이 36.8 \pm 34.5 분으로 TOVS군에서 시간이 더 짧은 경향을 보였으나 통계학적인 유의성은 없었다 $(p=0.199)$. 입원 기간은 TLM군 이 $3.8 \pm 1.8$ 일, TOVS군이 $4.2 \pm 1.7$ 일이었으며 두 군 간에 유 의한 차이는 없었고 수술 중 출혈량은 TLM군, TOVS군 모 두에서 최소 출혈량을 보였다. 술 후 합병증에서 재수술이 필요한 재출혈 사례가 TLM군에서 하나, 술 후 외래 경과 관 찰 시에 재입원을 요할 정도로 통증을 호소했던 사례가 TOVS군에서 한 차례있었고 상기 환자는 거대 종양으로 제 거 병변이 넓은 환자였다(Table 2).

\section{고 찰}

양성 후두 종양은 이비인후과에서 흔히 만날 수 있는 질환
Table 1. Clinicopathologic characteristics of the patients

\begin{tabular}{lccc}
\hline & $\begin{array}{c}\text { TLM group } \\
(\mathrm{n}=44)\end{array}$ & $\begin{array}{c}\text { TOVS group } \\
(\mathrm{n}=41)\end{array}$ & $\begin{array}{c}\mathrm{p}- \\
\text { value }\end{array}$ \\
\hline Age (year) & $48.5 \pm 13.7$ & $52.5 \pm 12.7$ & 0.164 \\
& $(20-72)$ & $(19-77)$ & \\
Gender (male:female) & $26: 18$ & $27: 14$ & 0.523 \\
Body mass index $\left(\mathrm{kg} / \mathrm{m}^{2}\right)$ & $24.0 \pm 3.2$ & $25.3 \pm 4.1$ & 0.265 \\
Dentulous/edentulous & $43 / 1$ & $39 / 2$ & 0.518 \\
Tumor size (mm) & $10.0 \pm 6.1$ & $12.5 \pm 6.7$ & 0.067 \\
& $(2-27)$ & $(4-32)$ &
\end{tabular}

Pathologic diagnosis

Epiglottic cyst

Laryngeal papilloma

Lymphoproliferative

lesion

Fibrosis

Schwannoma

Granulation tissue

Lipoma

Hamartoma

Salivary gland tumor

Venous ectasia

Anticoagulation

medication

Vascular comorbidity

TLM: transoral laser microsurgery, TOVS: transoral videolaryngoscopic surgery

Table 2. Comparison outcomes of transoral laser microsurgery and Transoral videolaryngoscopic surgery

\begin{tabular}{lccc}
\hline & $\begin{array}{c}\text { TLM group } \\
(\mathrm{n}=44)\end{array}$ & $\begin{array}{c}\text { TOVS group } \\
(\mathrm{n}=41)\end{array}$ & $\begin{array}{c}\mathrm{p}- \\
\text { value }\end{array}$ \\
\hline Total operation time $(\mathrm{min})$ & $45.6 \pm 27.9$ & $36.8 \pm 34.5$ & 0.199 \\
Hospital stay (day) & $3.8 \pm 1.8$ & $4.2 \pm 1.7$ & 0.266 \\
Complications & & & \\
$\quad$ Post OP bleeding & $1(2.2 \%)$ & 0 & \\
$\quad$ Dental injury & 0 & 0 & \\
\hline
\end{tabular}

TLM: transoral laser microsurgery, TOVS: transoral videolaryngoscopic surgery, OP: operative

이며 외과적 절제가 기본적인 치료방법이다. 1972년 Strong과 $\mathrm{Jako}^{3}$ 에 의해 후두 종양의 새로운 수술적 치료 방법으로 $\mathrm{TLM}$ 이 소개되었다. 이 최소 침습적 방법으로 경부 절개를 하지 않고도 양성 및 악성 종양의 제거가 가능해졌으며 현미 경의 발전에 따라 확대된 영상으로 세밀한 조작이 가능해졌 다. 그러나 경성 후두경에 의해 노출되는 수술 시야가 제한 될 수 있으며 작은 직경의 후두경 내에서의 기구 조작이 어 렵고 레이저의 직진성에 따른 절제각의 한계가 있을 수 있 다. ${ }^{14)}$ 또한 레이저 광선이 금속 물체에 닿아 반사되어 눈에 도 달하면 각막 손상을 일으킬 수 있으며 기관 내 삽관 튜브가 손상이 될 경우 산소 유량이 높으면 화재가 일어날 수 있다 
는 단점도 있다. ${ }^{3)}$

2010년 Shiotani 등'에 의해 후두 및 하인두 병변에 대한 외과적 절제의 또 다른 방법으로 TOVS가 소개되었고 그 이 후 주로 악성 후두 종양에서 효과적으로 시행되었다는 보고 들이 있었다. ${ }^{10-12)} \mathrm{TLM}$ 과 비교하여 이들이 제시한 유용성은 다음과 같다. 첫째, TOVS에 사용되는 내시경은 수술 보조자 의 조작에 의해 더 깊은 심도와 넓은 시야각을 확보할 수 있 기 때문에 경성 후두경으로 제한된 수술 시야만 인식할 수 있는 TLM의 현미경과 비교하여 수평 및 수직 방향 모두에 서 훨씬 더 넓은 수술적 시야를 제공할 수 있다. 둘째, TLM 의 경우 환자와 집도의 사이에 현미경이 있어 수술 기구의 조작에 제한이 있는 반면 TOVS는 내시경과 수술 기구가 함 께 삽입되므로 기구 조작이 더 용이하다. 셋째, TLM의 경우 후두경의 제한된 시야로 인해 종양의 크기에 따라 블록 절제 (blockwise resection)가 필요한 경우가 있지만 TOVS는 더 넓은 수술 시야로 일차 종양 절제(enblock resection)가 대부 분 가능하여 술 후 좀 더 정확한 병리학적 평가가 가능하다 는 장점이 있다. ${ }^{15}$

그러나 이러한 보고들은 악성 종양의 치료 결과에 집중되 어 있어 후두 양성 종양에서의 결과는 보고된 바가 없다. 따 라서 본 연구에서는 수술이 필요한 양성 후두 종양이 있는 환자들을 대상으로 TLM을 시행한 환자군과 TOVS를 시행 한 환자군으로 나누어 환자들의 임상양상 및 수술 결과를 비교 분석한 결과 두 군 간에 임상병리학적 요인 및 수술 결 과에서 유의한 차이를 확인할 수 없었다. 그러나 TOVS군에 서 TLM군에 비해 상대적으로 종양의 크기가 큰 것으로 나 타났는데(TOVS군: $12.5 \pm 6.7 \mathrm{~mm}$, TLM군: $10.0 \pm 6.1 \mathrm{~mm}$ ) 집도의가 수술적 방법을 선택할 때 종양의 크기가 큰 환자에 서 시야가 더 우수하고 기구 조작이 더 용이한 TOVS를 우 선적으로 선호했던 선택편향이 있었을 것으로 생각된다. 그 럼에도 불구하고 상대적으로 TOVS군에서 TLM군에 비해 수술시간이 짧은 경향을 보였는데(TOVS군: $36.8 \pm 34.5 \mathrm{~min}$, TLM군: $45.6 \pm 27.9 \mathrm{~min}$ ) 이는 TOVS의 경우 개방 경부 수 술에 익숙한 집도의가 TLM보다 넓은 수술 시야에서 양손 을 사용하여 보다 능숙하게 기구를 조작할 수 있었던 것이 하나의 원인으로 생각된다.

TOVS의 또 다른 장점은 레이저의 지혈 효과보다 우수한 전기 소작기를 이용할 수 있기 때문에 수술 중 지혈에 대한 대처를 보다 쉽게 할 수 있다는 것이다. 술 후 합병증에서도 재수술이 필요했던 재출혈 사례가 TLM군에서 한 사례 있었 으나 TOVS군에서는 재출혈 합병증이 발생하지 않았다. 전기 소작기의 지혈 효과가 우수한 반면 원하는 부위에 예리하게 지혈을 할 수 있는 레이저에 비해서는 그 효과가 떨어져 주변
조직에 열손상이 가해질 위험성이 커질 수 있다. 이를 보완하 기 위해 주요 구조물 주변에서는 전기 소작기의 절개 모드 (cutting mode)를 사용하였으며 술 후 주요 구조물의 손상은 없었다. 또한 고가 장비인 수술 현미경과 레이저 장비에 비해 TOVS 장비는 상대적으로 높은 가격 경쟁력을 가지고 있어 TLM 시스템이 없거나 준비되지 않은 경우 활용도가 높을 것 으로 판단된다. 또한 TLM 장비에 비해 TOVS 장비는 이동이 간편한 장점도 있다.

본 연구는 후향적인 분석으로 진행되어 선택편향 등의 한 계점이 있을 수 있다. 그러나 두 군 간에 환자들의 임상병리 학적 요인에 유의한 차이는 없는 것을 확인하였다. 또한, 3 명 의 외과의가 수술을 시행하여 이에 따른 교란변수는 있을 수 있을 것으로 생각되나 3 명 모두 한 기관에서 5년 이상의 두경부 수술 경력을 가지고 있어 수술 방법 및 숙련도에는 유의한 차이가 없을 것으로 판단되었다. 양성 후두 종양 수 술 시에 어떤 수술 방법이 유용성 및 안정성 등에서 더 우수 한지는 향후 전향적인 연구를 통해 확인할 필요가 있다.

TOVS는 양성 후두 종양 환자에서 안전하고 효과적으로 시행될 수 있으며 TLM과 비교하여 유의한 수술 결과의 차 이를 보이지 않았다. 따라서, TOVS는 양성 후두 종양의 수 술적 치료 방법으로 고려될 수 있겠다.

\section{Author Contribution}

Conceptualization: Hyoung Shin Lee, Sung Won Kim. Data curation: Ji Ah Song, Chang Hoi Kim, Jun Sang Cha. Formal analysis: Ji Ah Song. Investigation: Ji Ah Song, Hyoung Shin Lee. Methodology: Hyoung Shin Lee, Sung Won Kim, Kang Dae Lee. Supervision: Hyoung Shin Lee, Kang Dae Lee. Validation: Hyoung Shin Lee. Writing - original draft: Ji Ah Song. Writing — review \& editing: Hyoung Shin Lee.

\section{ORCID}

Hyoung Shin Lee https://orcid.org/0000-0002-6200-1979

\section{REFERENCES}

1) Kim HS. Benign laryngeal disorders. Korean J OtorhinolaryngolHead Neck Surg 2013;56:332-8.

2) Vilaseca-González I, Bernal-Sprekelsen M, Blanch-Alejandro JL, Moragas-Lluis M. Complications in transoral $\mathrm{CO} 2$ laser surgery for carcinoma of the larynx and hypopharynx. Head Neck 2003; 25(5):382-8.

3) Strong MS, Jako GJ. Laser surgery in the larynx. Early clinical experience with continuous CO 2 laser. Ann Otol Rhinol Laryngol 1972;81(6):791-8

4) Martin A, Jäckel MC, Christiansen H, Mahmoodzada M, Kron M, Steiner W. Organ preserving transoral laser microsurgery for cancer of the hypopharynx. Laryngoscope 2008;118(3):398-402.

5) Steiner W, Fierek O, Ambrosch P, Hommerich CP, Kron M. Transoral laser microsurgery for squamous cell carcinoma of the base of the tongue. Arch Otolaryngol Head Neck Surg 2003;129 (1):36-43.

6) Steiner W, Ambrosch P, Hess CF, Kron M. Organ preservation by 
transoral laser microsurgery in piriform sinus carcinoma. Otolaryngol Head Neck Surg 2001;124(1):58-67.

7) Iro H, Waldfahrer F, Altendorf-Hofmann A, Weidenbecher M, Sauer R, Steiner W. Transoral laser surgery of supraglottic cancer: Follow-up of 141 patients. Arch Otolaryngol Head Neck Surg 1998;124(11):1245-50.

8) Ambrosch P, Kron M, Steiner W. Carbon dioxide laser microsurgery for early supraglottic carcinoma. Ann Otol Rhinol Laryngol 1998; 107(8):680-8.

9) Shiotani A, Tomifuji M, Araki K, Yamashita T, Saito K. Videolaryngoscopic transoral en bloc resection of supraglottic and hypopharyngeal cancers using laparoscopic surgical instruments. Ann Otol Rhinol Laryngol 2010;119(4):225-32.

10) Yamashita $T$, Tomifuji M, Araki K, Kurioka $T$, Shiotani A. Endoscopic transoral oropharyngectomy using laparoscopic surgical instruments. Head Neck 2011;33(9):1315-21.
11) Shiotani A, Tomifuji M, Araki K, Yamashita T. Transoral videolaryngoscopic surgery for en bloc resection of supraglottic and hypopharyngeal cancers. Otolaryngol Head Neck Surg 2011;144 (2):288-9.

12) Tomifuji M, Araki K, Yamashita $T$, Shiotani A. Transoral videolaryngoscopic surgery for oropharyngeal, hypopharyngeal, and supraglottic cancer. Eur Arch Otorhinolaryngol 2014;271(3):589-97.

13) New GB, Erich JB. Benign tumors of the larynx: A study of seven hundred and twenty-two cases. Arch Otolaryngol 1938;8(6):841-910.

14) Park YM, Lee WJ, Lee JG, Lee WS, Choi EC, Chung SM, et al. Transoral robotic surgery (TORS) in laryngeal and hypopharyngeal cancer. J Laparoendosc Adv Surg Tech A 2009;19(3):361-8.

15) Imanishi Y, Ozawa H, Sakamoto K, Fujii R, Shigetomi S, Habu N, et al. Clinical outcomes of transoral videolaryngoscopic surgery for hypopharyngeal and supraglottic cancer. BMC Cancer 2017; 17(1):445. 